\title{
International Trade and Foreign Affairs - Some Reflections on Economic Diplomacy
}

\author{
Pierre-Bruno Ruffini*
}

\begin{abstract}
Economic diplomacy refers to methods and processes by which states take advantage of cross-border economic activities to achieve their national interests. It makes connections between the sphere of corporate players, who export or invest abroad, and the sphere of diplomats, who represent the state on the international scene and implement geopolitical decisions. The main purpose of this paper is to provide an overall and coherent framework for asking, classifying and discussing the main issues raised by economic diplomacy. It investigates concepts such as national interest, power and influence. It surveys the relevant literature and deals with various expressions of economic diplomacy such as export promotion agencies, economic role of embassies and consulates, or international economic sanctions. It analyzes the two-way relationship between international economics and international politics, which is at the core of economic diplomacy, and tries to answer the following questions: on the global scene, is diplomacy just accompanying the economy? Is diplomacy driving the economy?
\end{abstract}

Key Words: Diplomacy, Power, Embassies

Classification JEL: F5

Submission Date: 18/02/2016 Revision Date: 01/03/2016 Acceptance Date: 11/04/2016

* Professor of Economics Faculty of International Affairs

EDEHN - Equipe d'économie Le Havre-Normandie University of Le Havre - France pierre-bruno.ruffini@univ-lehavre.fr 


\section{Introduction}

What do international trade patterns depend of? The great bulk of trade economists answer this question by pointing the role of differences of productivity across countries, disparities of natural resources and factor endowments, market imperfections or strategic behaviors of suppliers on the global scene. All these determinants constitute the economic fundamentals of international trade and they are indeed major references for answering basic questions such as "who trades with whom and for what products". Every "traditional" and "new" theory of international trade brings a piece of the answer, explaining what the volume and the nature of international trade depend on, or more precisely what they would depend on, should only economic forces be at work.

The fact is that economic forces are not playing alone. This is a banal remark, drawing from ordinary observation of the reality of international trade. Many other non-economic (cultural, geographical, sociological $\cdots$ ) factors contribute to shape international trade. Among them, a particular attention is given here to political factors. Exports or imports are not only driven by interests and behaviors of private agents, suppliers or demanders of goods and services dealing with foreign partners. Governments (or synonymously here, states), which exercise authority over politically organized sovereign nations, are involved in international trade. They establish the nation's commercial foreign policy and decide of instruments to implement it. They may team up with other countries and agree on a common trade policy. Or they may try to exert a unilateral influence on other countries. Such decisions and actions have an impact on the volume, the content and the direction of trade flows.

They go along and amplify the workings of "pure" economic forces, or on the contrary, they may counteract and divert spontaneous trade flows between countries. These are the political factors that drive international trade.

In this very complex nexus of economic and political factors, a particular attention is given in this paper in the way they combine one with another. There are situations where a country's foreign trade policy is designed in order to achieve political goals. In reverse, there are situations where states use of their power and influence to achieve economic goals on the global scene. These interactions constitute the core issue of this paper. Our aim here is to enlighten them from a particular perspective, the one of economic diplomacy. These are words that may sound like heralding more of a practical and in-the-field rather than theoretical approach. This is only a part of the truth. Economic diplomacy is an activity and a subject for academic study. As we will try to demonstrate in the limited format of this paper, economic diplomacy is a fertile starting question and a useful thread for walking 
through the combined operation of economics and politics in international trade, both empirically and theoretically.

Economic diplomacy stands at the interface between international economics and international politics. It deals with interactions - and also tensions - between these two spheres. In a first attempt it can be defined as the methods and processes by which states take advantage of cross-border economic activities to achieve their national interests. Economic diplomacy is a complex matter. It covers a set of practices and involves a wide range of state and non state actors, from diplomats and other government officials to businessmen and bankers, as well as non-governmental organizations. Economic diplomacy is concerned with the relationships between two rather different spheres, the sphere of political diplomacy and foreign affairs, on the one hand, and the sphere of foreign trade and international business, on the other. In economic diplomacy, interests of states and of private companies get involved in an intimate way.

The purpose of this article is to try to untangle the relations and the mutual influences which exist between the world of diplomacy and the world of international economic relations, mostly understood in this article as international trade. This is a vast field, of which only pieces are covered by the existing empirical literature. When necessary, milestones of this literature will be surveyed in the paper. But our main goal here is conceptual: it is to provide an overall and coherent framework for asking, classifying and discussing the main issues that any questioning of the topic of economic diplomacy should raise.

The remainder of the paper is organized as follows. Section 2 tries to clarify the definition of economic diplomacy in order to overcome ambiguities that sometimes hang over this notion. Section 3 discusses more deeply key concepts and analytical backgrounds of economic diplomacy. Section 4 addresses the core issue of the inter-relationships between international trade and diplomacy. Section 5 concludes.

\section{What is economic diplomacy?}

\subsection{Diplomacy}

Diplomacy is the use of dialogue, negotiation and representation in international relations. It refers to actions and means other than the use of force or coercion, by which a country defends and promotes its interests and values in its relations with other countries. Diplomacy is also a profession and a career: it is the role of diplomats to find arrangements 
between competing interests and avoid confrontations. Diplomacy is one of the instruments of foreign policy, it contributes to its implementation but should not be confused with it 1 ).

Diplomacy stems from and expresses national sovereignty on the international stage. It is traditionally the exclusive privilege of sovereign states. In this sense, diplomacy is born with the modern system of states that emerged from the Treaty of Westphalia (1648) and the organization of international relations that has resulted. This model has dominated for nearly five centuries international relations. Today's diplomacy stands out in many ways because of the major changes it has undergone. Diplomacy today not only cares of state to state relations (bilateral diplomacy) but also of issues that affect several countries at once (multilateral diplomacy). Although states retain a prominent role, non state actors play an increasing role in the diplomatic game: non-governmental organizations, on behalf of the civil society, and multinational companies, representing the business community, are large families of private actors that are gaining ground in the international system. A third fundamental shift is the growing importance of diplomacy of influence, to which the identification of soft power has paved the way. Finally, with the expansion of its intervention areas, today's diplomacy offers a striking contrast with the diplomacy of the past, which limited its initiatives to political issues. Today we talk about economic diplomacy, energy diplomacy, environment diplomacy, nuclear diplomacy, science diplomacy, cultural diplomacy, digital diplomacy, etc. For clarity of vocabulary, note that "diplomacy" without any adjective refers to political (traditional) diplomacy. But "diplomacy", with the addition of a qualifier (cultural, environmental, or economic), refers to two aspects. One is instrumental: the use in a specific area of diplomatic instruments (negotiation), structures (embassies and consulates) and personnel (diplomats). The other aspect is more general and essential. It refers to the dimension of national interest: whatever field is looked into, using the word "diplomacy" means that a focus is made on international relations in the designated area and on their (direct or indirect) link with national interests.

\subsection{Economic diplomacy}

Let us start from several definitions of economic diplomacy gathered in the recent literature. According to Bayne and Woolcock, economic diplomacy is "about how states conduct their international economic relations ( $\cdots)$; how they make decisions domestically; how they negotiate with each other internationally; and how these two processes interact"2).

1) The use of the armed forces is the other major instrument of foreign policy.

2) Bayne N. and S. Woolcock (2003), The New Economic Diplomacy - Decision Making and Negotiation in international Economic Relations, Aldershot: Ashgate, p. 3. 
These authors add that economic diplomacy "is concerned with the interaction between international and domestic factors and economic and political concerns" 3 ): international trade negotiations, for instance, lie at the borderline between foreign and domestic policy. Van Bergeijk states that the aim of economic diplomacy "is to influence decisions about cross-border economic activities (export, import, investment, lending, aid and migration) pursued by governments and non state actors"4). And according to the Diplo Foundation, "economic diplomacy deals with the nexus between power and wealth in international affairs"5).

Each of these definitions captures one or several major aspects of economic diplomacy. We emphasize here what we believe essential for a sound understanding.

\subsubsection{States are key players of economic diplomacy}

As Bayne and Woolcock put it, "economic diplomacy is mainly concerned with what governments do"6). We must understand here "government" in a broad sense, including ministries and other administration bodies, public agencies, parliaments $\cdots$ all of them contributing to the definition and expression of government policies. Diplomacy in general is one of the attributes of a nation's sovereignty. It follows that economic diplomacy is a responsibility of sovereign states and considering it at any other level is just irrelevant. There is a French, an American or a Korean economic diplomacy, but companies like Michelin, Google or Samsung, although they have an international strategy, do not have a "diplomacy" of their own. This does not mean that these prestigious firms should be excluded from the analysis, and indeed the role that multinational companies play in economic diplomacy is widely acknowledged, as well as the role of consumerist organizations, which may launch boycott slogans, or the role non-governmental organization which can interfere in production and trade decisions for reasons related to food safety, environment, human rights or religion. The key condition to be fulfilled for private companies or non-governmental organizations to enter in the scope of economic diplomacy, and accordingly in the scope of the present study, is this one: these actors must behave in a way that is linked one way or another to foreign affairs and national interests.

\footnotetext{
3) Op. cit., p. 9.

4) Van Bergeijk P. A. G. (2009), Economic Diplomacy and the Geography of International Trade, Cheltenham: Edward Elgar, p. 1.

5) http://www.diplomacy.edu/courses/Economic

6) Op. cit., p. 6 .
} 


\subsubsection{There are two main levels of economic diplomacy: bilateral and multilateral}

Bilateral economic diplomacy takes place in country to country relations. It is the most traditional expression of economic diplomacy, and it is as old as international trade itself. Traditional missions of bilateral economic diplomacy consist in negotiating and monitoring bilateral treaties (related to trade, capital movements, taxation $\cdots$ ), help domestic firms in getting a foothold on foreign markets, and protect and defend their interests. Multilateral economic diplomacy involves several countries, be at a regional (European Union, NAFTA, ASEAN $\cdots$ ) or global level (WTO $\cdots$ ). At the global level, economic diplomacy is mostly concerned with negotiating international treaties and building global economic governance.

\subsubsection{Economic diplomacy uses a wide array of instruments}

As might be expected, negotiations and establishment of treaties are central in economic diplomacy, whether at bilateral or multilateral level. Diplomatic representation abroad (embassies, consulates) is the necessary infrastructure through which a state establishes and maintains external relations with other states. Instruments of economic diplomacy fall in two categories: proactive instruments, such as state visits, export promotion, negotiation of bilateral or multilateral treaties, economic summits7), aiming at creating positive interaction between countries; and reactive instruments, such as boycott, embargo or other sanctions, which express negative interaction with other countries. ${ }^{8)}$

It should be noted that the scope of economic diplomacy is large, and goes beyond the traditional and extensively commented field of trade diplomacy: country to country flows of goods and services, capital movements, international aid, taxation-related international arrangements, monetary organization, migrations $\cdots$ are the main relevant fields for exercising economic diplomacy. In the limited format of this paper, we will however focus mainly on trade diplomacy.

Finally, following the path put forward by Bayne and Woolcock, who regard "economic diplomacy as being defined not by its instruments but by the economic issues

7) N. Bayne argue that the G7 summit "provides an excellent laboratory for research and experiment in the study of economic diplomacy", in Bayne N. and S. Woolcock (2003), op. cit., p. 121.

8) Van Bergeijk P. A. G., op. cit., p. 181. 
that provide its content"9), we emphasize what is at the heart of economic diplomacy. As already mentioned, economic diplomacy's ultimate goal is to maximize national interest. Economic diplomacy makes the connection between two spheres, the sphere of international business, which is run by companies which export and invest abroad, and the sphere of foreign affairs, which is run by diplomats. Its core is made of the two-way relationship between these two spheres. Basically, a country's diplomacy can support and facilitate international business undertaken by domestic firms. But in reverse, a country's diplomacy can also make use of economic tools to reach pure political goals.

\section{Analytical background and concepts}

We turn now to the analysis of the main drivers and mechanisms of economic diplomacy. From what precedes, we understand that concepts such as national interest, power and influence are key ones for this matter. We must clarify what these notions mean, all the more that they do not belong to the economist's usual toolbox.

\subsection{National interest}

A basic assumption of the analysis of international political relations is that every national government is empowered to express and promote the nation's preferences and interests. On the global stage and for what concerns economic matter, this means that the government is supposed to ensure that international trade and capital mobility improve the Nation's welfare. International relations are the playing field where national preferences and interests meet, confront and accommodate themselves. Diplomacy, as already mentioned, aims at making each country's own interest compatible with interests of others through dialogue and negotiation rather than violence. In economic diplomacy, as in any other form of interstate relations, the cooperation-competition duality is found. The empirical literature on the trade-growth relationship and on the openness- performance relationship actually supports the view that the benefits of foreign trade are significant and substantial. This is why governments have a keen interest in foreign trade and investment. But in other situations, competition prevails, and the advancement of a country's national interest may happen at the expense of others.

9) Op. cit., p. 7. 
As economic diplomacy builds connections between the world of international business and the world of foreign affairs, a question is worth of attention: on the international scene, do firms have the same interests as their country's government? A traditional view is that successful companies bring benefits to their country as a whole: this is the famous "What is good for the country is good for General Motors - and vice versa" of Charlie Wilson, the former General Motors chief who became Secretary of Defense to President Eisenhower. A major mission of economic diplomacy is indeed to encourage the presence of domestic firms on foreign markets, through exports and direct investment. A view of a simplistic patriotism sometimes equates domestic enterprises to a sports team: firms must harvest economic successes on foreign markets just as sportsmen must win medals in international competitions.

But this issue is controversial. Situations where business interest and government interest do not match are not rare. Multinational companies usually practice tax optimization at a global scale, which generally represents a fiscal revenue shortfall for their home country. With foreign direct investment, companies may give priority to job creations abroad rather than in their home country. And off- shoring practices in international production make it difficult today to know the true "nationality" of a final product: according to OECD statistics, the import content of output rose from $30 \%$ to nearly $40 \%$ from mid-1990s to mid-2000s for the motor vehicles industry. It results that the nationality of products becomes less clear, just as the true economic nationality of multinational companies is sometimes unclear, with production sites scattered all over the world, shareholders and other funding sources coming from various financial markets, and executive teams truly multinational. These examples show that the interests of the state and those of companies may differ.

\subsection{Power}

We have several times used the word "power" in what precedes. This notion needs to be looked into more precisely. The power we speak about is the power of states on the international scene. Balance of powers between countries, conflicts, cooperation, are situations that need to be accounted for.

Mainstream neoclassical economics is not comfortable with studying such situations, one reason being that power is not quantifiable. The study of a nation's power does not fall into traditional analytical frameworks. François Perroux (1903-1987), one among the few economists that explored the issue of power, noted that "strength, power and coercion are congenitally foreign objects to modern economics, which its most recent improvements 
have failed to integrate"10). Certainly, microeconomic analysis and the theory of markets report on disparities of power between economic agents. Imbalances between demand and supply are privileged situations for observing the power that one side of the market holds over the other: canonical situations are "buyer's market" and "seller's market" (or "borrower's market" and "lender's market" for funding) on which values of price elasticity give an approximate measure of power. And in situations of imperfect competition, firms can exert a "market power" and act as "price makers". All this, however, does not make a complete and coherent theory of economic power.

The picture is even poorer in the field of traditional international economics. Although issuing international money or owning rare resources give obviously power to some countries with regard to others, such situations do not fit well with standard theories. Needless to add that there is no room in traditional theories for diverging interests and political dissensions between countries. Since A. Smith and D. Ricardo, the major concept that was established to the detriment of all the others is the one of "mutual advantages"11). Advantages eliminated power. Once countries specialize in international trade according to their comparative advantage, avoid subsidies and other distorting public policies, openness is superior to autarky and harmony prevails. Since then, free trade has been thought as a factor of peace. Echoing more than a century later the famous "Peace is the natural effect of trade" of the French political philosopher Montesquieu ${ }^{12)}$, the well-known thought leader of free trade Richard Cobden made the following plea: "I see in the Free-trade principle that which shall act on the moral world as the principle of gravitation in the universe,- drawing men together, thrusting aside the antagonism of race, and creed, and language, and uniting us in the bonds of eternal peace"13). This "make-trade-not-war" anthem inspired the commercial treaty of 1860 between England and France, and remains essential for understanding the liberalization of global trade that started soon after the end of Second World War.

Balance of power, negotiation, threat, conflict: these are words which practitioners of economic diplomacy are used to. But such a vocabulary does not exist in the prevailing academic vision of international economics, for which international trade is a mean of enhancing welfare in every participating country and generating a world of harmony. As

10) Perroux F. (1960), L'économie du XXe siècle, Paris : Presses universitaires de France, p. 70. Pouvoir et économie (1973) is Perroux's major writing on power.

11) Prior to Smith and Ricardo, however, the 18th century mercantilist doctrine did take into account the power of nations in international trade, and did not consider economics and politics as separate fields.

12) The Spirit of Laws (1748), Translated by Thomas Nugent (1750), Vol. 1, Chap. 4 (2). http://press-pubs.uchicago.edu/founders/documents/vlch4s2.html - The University of Chicago Press

13) Cobden R. (1870), Speeches on Questions of Public Policy. Vol. 1 Free Trade and Finance, London : T. Fisher Unwin. 
van Bergeijk points, "most textbooks in international economics do not pay attention to the inherent political character of international economic exchange"14). There is however a school of thought that has taken distance with the mainstream consensus, and endeavors to bridge international politics and international economics: we mean international political economy, an interdisciplinary academic field which draws both on political science and international economics. It is worth to be considered here for two reasons. First, it fully recognizes the political dimension of international economic relations. Kindelberger's Power and Money or Baldwin's Economic Statecraft are illustrations of this approach ${ }^{15}$. The Marxist theory of imperialism can be attached to this strand: by drawing on observations of international trade made during the period of colonialism, it set that international politics was mainly driven by conflicts between countries willing to secure outlets16). The post colonial ("neocolonial") period saw the emergence of economic theories of domination and of dependency, inspired particularly by Latin- American economists ${ }^{17)}$. The international political economy approach is worth to be mentioned here due to its interest in the power of nations and the resulting balanced or imbalanced situations on the global scene. Remembering that economic diplomacy stands at the interface between international economics and international politics, there is no doubt that this approach can provide very useful enlightenments. Among the large set of seminal contributors to this discipline18), definitions of power by Susan Strange and by John Nye seem to us relevant and useful for clarifying the questions addressed in the present paper. Strange - whose name is probably the most often cited among the founders of international political economy as an academic discipline - identified four aspects of power - security, production, finance, and knowledge - enabling countries which hold them to "provide protection, make things, obtain access to credit, and develop and control authoritative modes of interpreting the world"19).

Joseph Nye, in turn, is credited with the now classic distinction between hard power and soft power20). In contrast to hard power, in which a state exercises coercion on others

14) Op. cit., p.1.

15) Kindleberger C.P. (1970), Power and Money: The Economics of International Politics and the Politics of International Economics, New York: Basic Books; Baldwin D.A. (1985), Economic Statecraft, Princeton: Princeton University Press. See also Knorr K. (1975), The Power of Nations: The Political Economy of International Relations, New York: Basic Books.

16) Lenin, V. I. (1917), Imperialism, the Highest Stage of Capitalism, London: Lawrence and Wishart (1948).

17) Raul Prebisch, Celso Furtado, André Gunder Frank among others.

18) Robert Gilpin, Robert Keohane, Dani Rodrik and many others.

19) In States and Markets (1988), London: Pinter.

20) Nye J. (1990), Bound to Lead: The Changing Nature of American Power, New York: Basic Books; (2004), Soft Power - The Means to Success in World Politics, New York: Public Affairs. 
by using the traditional tool of military power, soft power is the use of non-coercive means. As a third dimension of power alongside military power and economic power, soft power is "the ability to get what you want through attraction rather than coercion or payments"21). Soft power is also said to be the "power of co-optation" by which a country can exert influence by playing the seduction and persuasion, the objective being to bring others to share its values, to reproduce its models, to "think" the same way as it does. To achieve this, a country mobilizes resources such as image, reputation, prestige, communication skills, the attractiveness of its culture, its science and technology profile, etc. The variety of modes of expression of soft power seems to have no limit: higher education (Harvard), film making (Hollywood), music (Korean Pop), humanitarian action (French Doctors) are assets that make countries attractive and are vehicles of soft influence. Nye summarized the differences between hard and soft power in Table 1 below 22 ):

Table 1.

Three Types of Power

\begin{tabular}{|c|c|c|c|}
\hline & Behaviors & Primary Currencies & Government Policies \\
\hline Military Power & $\begin{array}{l}\text { coercion deterrence } \\
\text { protection }\end{array}$ & threats force & $\begin{array}{c}\text { coercive diplomacy } \\
\text { war } \\
\text { alliance }\end{array}$ \\
\hline Economic Power & inducement coercion & payments sanctions & aid bribes sanctions \\
\hline Soft Power & $\begin{array}{l}\text { attraction agenda } \\
\text { setting }\end{array}$ & $\begin{array}{l}\text { values culture policies } \\
\text { institutions }\end{array}$ & $\begin{array}{c}\text { public diplomacy } \\
\text { bilateral and } \\
\text { multilateral diplomacy }\end{array}$ \\
\hline
\end{tabular}

We must note that, beyond its three basic components, the power that a state exhibits on the international scene makes up a whole. This has been more recently described as "smart power". This innovative concept in the field of foreign and security policy was defended in these terms by Secretary of State Hillary Clinton: "We must use what has been called "smart power", the full range of tools at our disposal -- diplomatic, economic, military, political, legal, and cultural -- picking the right tool, or combination of tools, for each situation"23). This integrated approach of smart power thus became the credo of the

\footnotetext{
21) Nye J. (2004), p. x.

22) Nye J. (2004), p. 31.

23) During her confirmation hearing before the Senate Foreign Relations Committee on January 13, 2009.
} 
present US administration, and is also central to the foreign policy of emerging countries like Brazil, China and India. In fact, if the combination of military, economic and soft components of power may vary overtime for a country, it also varies across countries: for instance, Japan and Germany exert a rather limited political influence on world affairs, have a limited military power but have a significant economic power; France on the contrary enjoy a rather strong soft power, and is more influential in international political affairs than on the global economic stage.

What are the lessons that can be drawn from this rapid overview of the concept of power for the understanding of economic diplomacy? The first lesson is obviously that there exists a relationship between economic power and economic diplomacy: the acknowledged importance of economic diplomacy today draws from the growing importance of economic and financial relations between countries in the age of globalization. But, second point, it draws also from the changing combination of types of power of major countries: these countries have become more reluctant to use military power, as the perceived cost of losses due to conventional weapons has become higher than in the past, not mentioning the cost of using nuclear weapons. In case of conflict, using economic tools rather than military ones - that is, using economic diplomacy - is at the same time more flexible and less costly. As we will see below, sanctions can be considered as an alternative to sending the army. The third lesson to draw is the existence of a link between economic power and soft power. According to Nye's taxonomy, economic diplomacy would be mainly concerned with economic power. We will indeed illustrate below on various examples how trade can be tightly associated with foreign affairs and be a source of political power in international relations. But when grounded on an economic basis, soft power can also have links with economic power. For instance, Hollywood is an unquestioned source of soft power for America, as a worldwide vehicle of American myths and culture. But it is also a prosperous business, generating billions of dollars of export income, and for all those reasons, American diplomats are leaders for demanding the freest trade regime that can be in the WTO arena. Similarly, French wines are at the same time a highly successful exporting industry and a vector of French traditional values and art de vivre, that is, a vector of soft power. 


\section{Interactions between international economics and diplomacy}

Several connections exist between political and economic relationships at the international level. We find in the literature contributions on the "trade follows the flag" topic, the flag being regarded as an expression of a country's foreign policy goals and national security interests 24 ). However, most of this literature deals with the trade-conflict relationship (Does international trade reduce the potential for conflicts between countries? What is the impact of wars on trade? Etc.). We leave aside this "trade and conflicts" literature, as conflicts differ from diplomacy (when conflicts erupt between countries, it means that diplomacy has failed to ease tensions - which does not mean that diplomats are inactive during conflicts). In this section we turn to interactions between international economic relations and diplomacy, which constitute the backbone of economic diplomacy.

International economic relations and diplomacy are different in nature:

- international economic relations (trade and foreign direct investment) are first of all transactional and contractual relations between private (or sometimes public) parties, and are driven by the private interests of businessmen and companies;

- diplomacy is a mode of relation between subjects of international public law (states or international organizations) which, in principle, express general interest and act accordingly.

Nevertheless, although they have different objectives, these two categories of actors can serve the same purpose: to assert the sovereignty and power of the nation in front of other nations. As already stressed, the relation between the sphere of foreign economic relations and the sphere of political and diplomatic goals is a two-way relation: trade, for instance, can serve pure diplomatic goals, and diplomacy can serve the interests of trade.

The literature provides several empirical studies. Typically, these studies look for significant relationships between variables representing foreign economic relations (figures of bilateral trade, most often) and variables representing diplomatic activity (state visits, size of budgets, number and location of embassies and consulates $\cdots)$. This helps answering the two questions that we address here: on the global scene, is diplomacy just accompanying the economy? Is diplomacy driving the economy?

24) The literature is surveyed in Bove V., L. Elia and P.G. Sekeris (2014), "US Security Strategy and the Gains from Bilateral Trade", Review of International Economics, 22 (5), 863-885. The phrase "trade follows the flag" is commented in these terms in the Brewer's Dictionary of Phrase and Fable (1870: "Colonies promote the trade of the mother country. The reference is to the custom of planting the flag of the mother country in every colony". 


\subsection{Foreign economic relations for diplomacy}

There may exist geo-strategic determinants of bilateral trade and capital flows. Foreign trade (and capital outflows or financial aid as well) have been for long used as instruments supporting the foreign policy of a country. But there are two very different types of situations: in the most frequent ones, foreign trade is used in a peaceful way to raise the international political influence of a country or a group of country. Other situations exist where foreign trade is used as a weapon to press on the outcome of a political dissension between countries.

\subsubsection{Foreign economic relations as a way of enhancing pure diplomatic (political) influence}

We give here examples of how a state can use trade and other foreign economic relations in a soft manner to raise its influence upon other states and draw political benefits on the international scene.

We turn first to the political goals of foreign trade policy. Disentangling the purely economic and political motives in commercial relations between two countries is not an easy task. Our view is that when trade flows arise and develop between two countries from corporate voluntary initiatives, they pave the way for closer official relations between these countries. When bilateral trade relations lead to the signing of a trade agreement, involving the gathering of political representatives and possibly the visit of heads of state, trade ceases to be only of trade: it becomes a political issue, it opens to institutional links between the two countries and may eventually favor other types of exchanges (technological, cultural). Thus, trade opens the door to diplomacy. It facilitates, at least for one of the two partners, the exercise of influence on the other country. Today's economic relationships between China and several African countries are a good illustration. Commercial positions acquired by Chinese firms in Africa are at the forefront of China's diplomacy in the continent. Since 2000, a ministerial conference (Forum on China-Africa Cooperation) has been held every three years. In 2013, Chinese President Xi Jinping made an historic tour in Tanzania, South Africa and the Republic of the Congo.

At the regional level too, foreign trade relations can play a political role. Experiences of free trade areas, customs unions or monetary unions can be addressed with a central question: what is the respective importance of the economic reasons and the political motives in the explanation of such groupings? In particular, what is the raison d'être of 
trade preferences and protectionism at the regional level?

No doubt that countries willing to team up in some sort of regional grouping have both types of motivations. However, the mix depends upon the degree of integration which is desired. In weak forms of regional commercial arrangements such as free trade areas, the political project is loose (North American Free Trade Agreement) or absent (European Free Trade Association): this is not really about integration. At the other end, the European Union, which is the most advanced form of regional integration to date, has been demonstrating since its inception that political integration is its main driver, to be approached step by step thanks to successive economic policies (customs union, single market for services, single currency). The Eurasian Customs Union (Russia, Belarus, Kazakhstan, Armenia), which was launched in 2010, gives another recent illustration of a union of countries using commercial policy instruments for creating a regional block where political mobiles (Russia's attempt to comfort its influence on former Soviet states) seem to be dominant.

We turn now to financial aid pursuing political goals. Credit and other financial assistance may give creditor countries opportunities of influence. This is obvious with tied aid credits, which "are official or officially supported loans, credits or associated financing packages where procurement of the goods or services involved is limited to the donor country or to a group of countries"25). Motivations for tying aid are both economical and political. Raising its own exports is the economic benefit of the donor country. However, this benefit may be only minimal. An OECD study mentioned that tied aid connected exports from nine representative European donors and 32 representative developing countries represented only $4 \%$ of total exports 26 ). This study concluded on the larger importance of political motivations, fuelled by historical relations, existing trade relationships, geopolitical interests and cultural ties.

Country to country loans may also create situations of political domination. The history of international credit offers numerous examples of borrowing countries unable to pay back their debt and which public budgets were placed under supervision of lending countries, from Egypt (1876) or China (1912) to ‥ Greece (2015). Although not premeditated, such crediting positions are a way of spreading influence. But the most convincing examples are those where the distribution of credit is deliberately devised as creating exclusive political relationships with recipient countries. An outstanding example is the one of the so-called "dollar diplomacy".

The experience of dollar diplomacy is associated with the term of President William

25) OECD, Glossary of statistical terms.

26) Jepma C. J. (1991), The Tying of Aid, OECD, Development Centre Studies. 
Howard Taft (1909-1913). During the pre-First World War period, the American foreign policy demonstrated how the use of trade and finance, symbolized by the nation's currency, could be a lever for raising the political influence of the United States on the world stage. According to Taft's words, "this policy has been characterized as substituting dollars for bullets"27) - a replacement of military power by economic power, could we say by using Nye's typology. Latin America and the Far-East were the two targeted areas. As Trani puts it, "the most important consideration was preservation of vital American interests abroad by helping underdeveloped countries establish viable governments and integrating them into the twentieth century"28). The State Department deployed at that time considerable activity in securing trade and investment opportunities abroad, in order to encourage and support American businessmen. This illustrates how tight a combination of interests of business and political spheres can be and how foreign economic relations and diplomacy interact: the ruling administration decided to use economic capabilities of the country for increasing its world political and diplomatic influence, and for that reason had to increase its assistance to American businessmen's initiatives on foreign markets.

At the regional level, the "Marshall Plan" (officially named "European Recovery Program") ranks among the most outstanding examples of economic and financial support fitting into a long term political vision. It illustrates quite well the use of economic tools for securing advantageous political positions on the world scene. This initiative of the US State Department was designed to help rebuild European economies after the Second World War. From 1948 to 1951, 16 European countries benefited of economic and technical assistance from the US, for a total amount of $\$ 13$ billion. Historians do not cast doubt over the fact that political mobiles were as much important as economic ones. For the Americans, preventing the spread of communist influence over Europe was one of the objectives of the Plan. In the context of the nascent Cold War, the Plan allowed the United States to exert a political influence over the West part of the Old Continent. The attitude of the Soviet Union confirmed this interpretation: the State Department offered Soviet Union to join the program, but Soviet Union refused and pressured its Eastern European allies to do the same.

\subsubsection{Foreign economic relations as a way of exerting coercion}

Economic sanctions are another side of the use of economic tools for pure diplomatic purposes. They take place in situations of tension or conflict between two (or several)

27) Trani E.P., "Dollar Diplomacy", Encyclopedia of the New American Nation http://www.americanforeignrelations.com/A-D/Dollar-Diplomacy.html

28) Ibid. 
states, where diplomatic dialogue is ineffective and military action seems inappropriate. Such sanctions are decided by one country (or several countries) and directed to another country (or several other countries). These coercive measures are a tool of foreign policy: the goal is to bring pressure upon a government to oblige it to change its behavior and political orientation. We note that the charter of United Nations, article 41, explicitly provides for the use of sanctions: "The Security Council may decide what measures not involving the use of armed force are to be employed to give effect to its decisions, and it may call upon the Members of the United Nations to apply such measures. These may include complete or partial interruption of economic relations and of rail, sea, air, postal, telegraphic, radio, and other means of communication, and the severance of diplomatic relations".

Economic sanctions include restrictions on trade or complete prohibition of trade (boycott, embargo) which can be limited to certain types of products (weapons, frequently). They also include freezing or confiscation of financial assets.

Economic sanctions are set for various reasons. They can be designed to force a country to abide by international law. In 1935-1936, the League of Nations imposed sanctions against Italy which had invaded Ethiopia. Following the invasion of Kuwait, the United Nations Security Council established sanctions against Iraq (1990-2003), with the objective of forcing this country to withdraw from Kuwait and eliminate weapons of mass destruction. In 2014, after Russia annexed Crimea and brought military support to Donbass separatists in their fight against the Ukrainian government, the European Union, the United States and other Western countries (Australia, Canada, Norway) decided to impose economic sanctions against Russia: ban on trading of shares of Russian banks in which the state is the majority shareholder, embargo on export and import of military equipment, on export of equipment related to energy and technology, assets freeze and visa ban for Russian officials. Russia retaliated by declaring an embargo on food product imports from the countries applying these sanctions.

Sanctions are sometimes motivated by the threat to security a country is supposed to represent: this was the case of American sanctions against Cuba in order to press the government to refrain its anti- American orientation (1961-2015), or of United Nations Security Council sanctions against Iran to urge this country to suspend its uranium enrichment program and give up its nuclear military goals (2006-2015). A very specific case was South Africa: in 1962, the United Nations General Assembly urged its members to voluntarily cease their economic and political connections with South Africa, in order to force the country to give up its policy of racial discrimination. This resulted in a diplomatic and economic isolation of South Africa on the international scene, until the regime changed and the apartheid policy was abandoned in 1994. 
Economic sanctions do change the geographical pattern of international trade and capital flows: products on which sanctions are applied are less traded, alternative trade flows may develop for the benefit of supplying countries which do not apply sanctions, various unofficial new commercial routes are created in order to bypass sanctions, etc. But the central issue is about the effectiveness of such measures. A quick look to policy orientations of countries such as China, Cuba, Iran or Israel - countries which, for varying durations, were subjected to international sanctions in recent decades - casts doubt on their effectiveness. The Peterson Institute for International Economics extensively investigated this topic ${ }^{29)}$ : based on 204 observations from World War I to 2000, its survey showed that only $34 \%$ of international sanctions contributed significantly to the partial or full achievement of foreign policy goals that were pursued. This low level of success can be explained, among other things, by divergence of state interests, effects on the civilian population and deviation from initial objectives, hampering the effectiveness of sanctions.

\subsection{Diplomacy for foreign economic relations}

The other side of the relationship must now be addressed: diplomatic action for supporting foreign economic relations, insofar as these relations improve welfare and serve the country's national interest. Support at the bilateral level has existed for long. Support at the multilateral level is more recent.

\subsubsection{Diplomacy for foreign economic relations at the bilateral level}

This is one of the most traditional roles of diplomacy to facilitate the nation's foreign trade. As stated by Lord Palmerston, who served as Foreign Secretary and Prime Minister in the middle of 19th century, "it is the business of Government to open and to secure the roads for the merchant"30). For several centuries, diplomats have negotiated commercial routes, have supported the creation of trade networks and negotiated commercial treaties. In the history of international trade, colonial expansion became a major diplomatic topic in mid-19th century. Beyond their colonial reach, great powers developed and consolidated their own area of influence. A major task of diplomats on foreign markets was to obtain for

29) Hufbauer, G. C., J.J. Schott, K.A. Elliot and B. Oegg (2008), Economic Sanctions Reconsidered, 3rd Edition, Washington, DC: Peterson Institute for International Economics.

30) In a letter to the Governor of India, 22 January 184, quoted by Goodlad M.L.E (2015), Victorian Geopolitical Aesthetic: Realism, Sovereignty, and Transnational Experience, Oxford: Oxford. University Press, p. 7. 
the nation's companies exploitation rights, commercial privileges, contracts for settling public utilities or building great infrastructures. Among the biggest deals on the international agenda of that time were maritime canals (Suez, Panama). By the end of the $19^{\text {th }}$ century, "oil diplomacy" appeared. Today, support to domestic companies on foreign market is even more essential. In all countries that aspire to have an active economic diplomacy, supporting national economic interests abroad is provided by two complementary structures: one or several export promotion services in the country, and economic missions at embassies and consulates abroad.

Export promotion services exist in all big exporting countries. They promote foreign trade mostly by giving information and advice to exporters, and work in close contact with other public agencies which facilitate funding and insurance of exports. In France, the exporting promotion agency is Business France, which is under the Ministry of Foreign Affairs and International Development, the Ministry of Economy and Finance and the Ministry of Rural Areas and Regional Planning. In the United States, there are 20 or so federal government agencies supporting U.S. exports, among which the Department of Agriculture (USDA), the Department of Commerce, Export-Import Bank (Ex-Im Bank) and the Office of the U.S. Trade Representative (USTR). Japan (JETRO, Japan External Trade Organization), Korea (Korea Trade-Investment Promotion Agency, KOTRA) or the United Kingdom (UK Trade and Investment) have their own export promotion agency, as every major exporting country.

Diplomatic representation abroad consists of embassies and consulates (sometimes also named "Foreign Service"). Diplomatic history teaches that from the outset such networks have performed an economic role. Consuls were established abroad in order to safeguard commercial national interests and to protect national citizens abroad. At the origin the first consuls were traders, entrusted by their pairs for representing and defending them, and empowered by their government for these missions. It is interesting to notice that permanent embassies and customs administrations were born in the same period $\left(16^{\text {th }}\right.$ century). Table 2 below shows the magnitude of diplomatic networks of major countries, which gives some indication on the capability of these countries to provide on-the-ground support to domestic companies expanding abroad. 
Table 2.

Number of embassies of major countries (2014)

\begin{tabular}{c|c}
\hline Country & Embassies \\
\hline United States of America & 172 \\
\hline France & 154 \\
\hline United Kingdom & 149 \\
\hline Germany & 149 \\
\hline Russia & 140 \\
\hline China & 130 \\
\hline Italy & 126 \\
\hline Japan & 122 \\
\hline Egypt & 117 \\
\hline Canada & 116 \\
\hline
\end{tabular}

Broadly speaking, export promotion agencies and diplomatic representations abroad have the same objective: to reduce the information gap which may hamper domestic firms when approaching foreign markets, where they have to face cultural and institutional particularities. The work done by export promotion agencies and diplomatic networks is complementary. Export promotion agencies help potential exporters to understand foreign markets and find outlets for their products. Adding to this first-type knowledge, in-the-field embassies and consulates bring information about local markets. They know the business climate and the history of the bilateral trade relationship with their host country. They are in a privileged position for detecting market opportunities and advising exporters and investors from the home country. In a word, these structures reduce the distance between home and foreign markets. They allow for lowering cultural, institutional and political intangible barriers, which negative impact is substantial: Anderson and van Wincoop, for instance, estimated that national borders reduce trade between Canada and the U.S. by about $44 \%$, and roughly $30 \%$ for other industrialized countries 31 ).

Are export promotion services and diplomatic representation effective? What it their impact on bilateral trade? Measuring the effectiveness of export promotion agencies has drawn some attention in the literature. The first studies that were conducted in the 1990s led to mixed or even negative conclusions for export promotion agencies, especially those of developing countries ${ }^{32}$ ). Studies from observations of the 2000s give a better picture, as they generally conclude that such agencies - partly because they have been retooled - have

31) Anderson J.E. and E. van Wincoop (2003), "Gravity with Gravitas, A Solution to the Border Puzzle", American Economic Review, 93 (1), 170-92.

32) For a review, see Lederman D., M. Olarreaga and L. Payton (2006), "Export Promotion Agencies: What Works and What Does Not", Trade Note - The Word Bank Group, 38420, September 30. 
a positive effect on exports. Lederman, Olarreaga and Payton surveyed data covering 103 developing and developed countries. Their econometrical study concluded that, on average, export promotion agencies have a statistically significant effect on exports. They estimated that each USD of export promotion resulted in a USD 300 increase in exports for the median export promotion agency33). Hayakawa, Lee and Park (2014) examined this issue for Japan and Korea ${ }^{34)}$. They established that for both countries, the role of the national export promotion agency had a positive effect on exports. They measured that the effects were larger when exporting to low-income trade partners than exporting to high-income ones.

The impact on foreign trade of diplomatic representations abroad also received attention in the literature. An influential contribution was the one of Rose (2005) who investigated if the amount of a country's exports was correlated with the size of its diplomatic representation abroad. Using a gravity model and cross-section data covering 22 large exporters and 200 import destinations for the year 2002, he calculated that adding a consulate abroad rose bilateral exports by approximately 6 to 10 per cent. The impact varied across exporting countries. He also showed that the creation of a consulate had smaller trade effects than the creation of an embassy. Van Bergeijk provided another useful empirical contribution 35 ). From results of a cross-section gravity equation applied to bilateral trade flows of 36 countries (covering half of the world trade) for year 2006, he concluded that export promotion agencies did not in general contribute to bilateral trade flows, whereas the Foreign Service significantly did ${ }^{36)}$. Investigating the relationship between trade and diplomacy in the context of transition to the market economy of East European countries, Afman and Maurel estimated for their part that the opening of an embassy had an impact equivalent to a tariff reduction of 2 to $8 \% 37$ ).

State visits should not be omitted when dealing with the support of diplomacy to external economic relations. State visits are a true component of economic diplomacy. They offer privileged opportunities to give an impulse to bilateral economic exchanges. When an official delegation (possibly led by the head of state) visits another country, it normally endorses cooperation agreements that have been prepared by diplomatic services on both

33) Lederman D., M. Olarreaga and L. Payton (2009), "Export Promotion Agencies Revisited”, World Bank Policy Research Working Paper, 5125.

34) Hayakawa K., H.-H. Lee and D. Park (2014), 'Do Export Promotion Agencies Increase Exports?', The Developing Economies, 52, 3, 241-261.

35) Op. cit., chap. 5.

36) Van Bergeijk P., op. cit., chapter 5.

37) Afman E. R. and M. Maurel (2014), "Diplomatic relations and trade reorientation in transition countries", in Peter A. G. van Bergeijk and S. Brakman (Eds), The Gravity Model in International Trade Advances and Applications, Cambridge, UK: Cambridge University Press, pp. 278-295. 
sides. In the aircraft that conveys delegations, there are generally company managers who take advantage of the political dimension of the visit to strengthen commercial and industrial relationships and increase market access. The economic impact of state visits has been tested econometrically: from an investigation over the period 1948-2003, Nitsch established a correlation between state visits of France, Germany and the United States to 200 export destinations and the rate of growth of exports to these partner countries, and estimated that a visit was typically associated with higher exports by about 8 to 10 per cen $\mathrm{t}^{38)}$.

\subsubsection{Diplomacy for foreign economic relations at the multilateral level}

At the multilateral level, economic diplomacy is primarily concerned with the management of global public goods. The concept of global public good refers to global issues, that is, to challenges that humanity must cope with in order to overcome risks threatening its survival. It results from the transposition at the international level of the concept of public good created in the 1950s by specialists of public economics. By extending this definition, a global public good has non-rivalry and non-exclusion characteristics, not only between individuals within a country, but also between people from different countries. When speaking of global public goods, it is believed most often the quality of climate and environment, human health or collective security. But public goods are not only those related to the physical conditions of human life. The way international relations are organized can also be looked into with the help of this concept: financial stability or the international trade regime are public goods ${ }^{39}$ ). Concerns about such global issues make multilateral economic diplomacy a consistent and of its time topic.

A proper management of global public goods is crucial. If well managed, the international trade regime or the international monetary organization generates positive externalities. This management (or governance) takes place within the frame of multilateral diplomacy, which is typically associated with the United Nations system.

An interesting aspect of multilateral economic diplomacy is the importance of economic expertise it requires. Economics, as a science, is an input of diplomacy. In-house expertise of departments may be insufficient for preparing international negotiations, for instance for making simulations of the impact of a possible tariff measure, etc. This is why academic experts are invited, and may exert a strong influence. Bayne reports that Prof.

38) Nitsch V. (2007), "State Visits and International Trade", World Economy, 30 (4), 1797-1816. For an in-depth discussion, see van Bergeijk, op. cit., pp. 86-89.

39) See for instance UNIDO (2008), Public Goods for Economic Development, Vienna. 
John Jackson, an academic at the University of Michigan, was very influential in the conversion of the GATT into the WTO40). Besides their role in the preparation of multilateral negotiations, academic expert may also be very influent in the agenda setting, by identifying issues that need to be debated at the global level. It is a well know fact that analyses and arguments of the dependency theory promoted by Latin American scholars have helped impose the topic of the New Economic International Order (NEIO) on the international agenda in 1974.

\section{Concluding remarks}

Interactions between international economics and international politics make a complex nexus. We have tried in this paper to address this wide topic from the perspective of economic diplomacy. Economic diplomacy lies at the crossroads of international economics (international trade, international capital flows) and international politics (foreign affairs). It makes connections between two spheres: the sphere of corporate players, who take business decisions such as exporting or investing abroad, and the sphere of diplomats, who represent the state on the international scene and implement geopolitical decisions.

Our starting point was the following: international trade patterns are not only shaped by pure economic factors, such as differences in productivity or factor endowments between countries. They are also shaped by political factors. In order to take them into account, we focused on two major concepts - national interest and power - which are not primarily economic ones but belong to the vocabulary of international politics. This has provided us with arguments in favor of international political economy. This approach gives an appropriate analytical framework for studying the way political and economic factors intermingle on the international scene. In this sense, our paper advocates against compartmentalization of disciplines.

Economic diplomacy is one of the many connections that exist between international political relationships and trade and capital flows. A major part of the paper was devoted to analyzing the two-way relation between trade and diplomacy: international trade can help to fulfill pure diplomatic goals, and in reverse diplomacy can serve the interests of trade. Analyzing each of these two channels allowed for identifying and sorting several sub-issues, which we have successively reviewed. There exist geo-strategic determinants of international economic relations: foreign economic affairs can enhance the political

40) Op. cit., p. 70. 
influence of a country over some others, foreign trade can open the door to diplomacy and financial aid can create political dependency of recipient countries on donor countries. But foreign economic relations can also be a tool for exerting coercion: a country may decide to apply economic sanctions to another (boycott, embargo, banking asset freezing $\cdots$ ) in order to force it to revise its political choices. We also addressed the other side of the relationship between diplomacy and trade. Governments have for long favored the presence of domestic firms on foreign markets through export promotion agencies and diplomatic representation abroad (embassies and consulates), both forms of support on which empirical studies bring significant evidence. At the multilateral level, diplomacy supports trade and business by participating in the governance of economic globalization.

At the end of these pages devoted to economic diplomacy, we hope we have made convincing arguments that foreign policies and the power of states have a strong influence on patterns of trade between countries, and this should not be overlooked by scholars in international economics. It seems that at least two set of issues would deserve further attention. We have devoted a large part of this paper to analyzing the relationships between the interests of political diplomacy and those of the business world. Common sense and econometric studies suggest that the foreign policy of a country and its external economic relations can be correlated. But it is rather difficult to decide on the direction of causality, and no doubt that in many cases the developments of a country's diplomacy and that of its foreign economic affairs are mutually reinforcing. For example, the visit of a head of state in a foreign country often comes after companies have created bilateral trading relations. But such an official visit may also give a new impetus to bilateral economic relations. Similarly, a country may decide to increase its diplomatic representation in another country or another region, because its trade with this country or region develops. But in turn that extra diplomatic presence can strengthen and enhance bilateral exchanges. Following here van Bergeijk ${ }^{41}$, we think that improving the knowledge about causality in economic diplomacy should be a priority on the research agenda.

Such a question is not only a theoretical one, it is all the more important that it is also related to policy making. From the government's perspective, economic diplomacy is a public policy and as such, it must be guided by principles, both for decision-making and for evaluation. Governments have to know for instance about the impact of the Foreign Service on the country's economic power and influence on the international scene. For this additional reason, we regard as desirable the development of scientific studies on economic diplomacy.

41) Op. cit., pp. 176-177. 


\section{REFERENCES}

Afman E. R. and M. Maurel (2014), "Diplomatic relations and trade reorientation in transition countries", in Peter A. G. van Bergeijk and S. Brakman (Eds), The Gravity Model in International Trade - Advances and Applications, Cambridge, UK: Cambridge University Press, pp. 278-295.

Anderson J.E. and E. van Wincoop (2003), "Gravity with Gravitas, A Solution to the Border Puzzle", American Economic Review, 93 (1), 170-92.

Bayne N. and S. Woolcock (2003), The New Economic Diplomacy -Decision Making and Negotiation in international Economic Relations, Aldershot: Ashgate.

Bove V., L. Elia and P.G. Sekeris (2014), "US Security Strategy and the Gains from Bilateral Trade", Review of International Economics, 22 (5), 863-885.

Hayakawa K., H.-H. Lee and D. Park (2014), "Do Export Promotion Agencies Increase Exports?", The Developing Economies, 52, 3, 241-261.

Hufbauer G. C., J.J Schott, K. A. Elliot and B. Oegg (2008), Economic Sanctions Reconsidered, $3^{\text {rd }}$ Edition, Washington, DC: Peterson Institute for International Economics.

Jepma C. J. (1991), The Tying of Aid, OECD, Development Centre Studies.

Lederman D., M. Olarreaga and L. Payton (2006), "Export Promotion Agencies: What Works and What Does Not", Trade Note - The Word Bank Group, 38420, September 30 .

Lederman D., M. Olarreaga and L. Payton (2009), "Export Promotion Agencies Revisited", World Bank Policy Research Working Paper, 5125.

Nitsch V. (2007), "State Visits and International Trade", World Economy, 30 (4), 1797-1816. 
Nye J. (1990), Bound to Lead: The Changing Nature of American Power, New York: Basic Books.

Nye J. (2004), Soft Power - The Means to Success in World Politics, New York: Public Affairs.

Perroux F. (1960), L'économie du XXe siècle, Paris : Presses universitaires de France.

Strange S. (1988), States and Markets (1988), London: Pinter.

Trani E.P., "Dollar Diplomacy", Encyclopedia of the New American Nation.

http://www.americanforeignrelations.com/A-D/Dollar-Diplomacy.html

UNIDO (2008), Public Goods for Economic Development, Vienna.

Van Bergeijk P. A. G. (2009), Economic Diplomacy and the Geography of International Trade, Cheltenham: Edward Elgar. 